\title{
Zinc Methionine Supplementation Impacts Gene and Protein Expression in Calf-Fed Holstein Steers with Minimal Impact on Feedlot Performance
}

\author{
J. E. Hergenreder ${ }^{1}$ • J. F. Legako ${ }^{4}$ • T. T. N. Dinh ${ }^{5}$ - K. S. Spivey ${ }^{1}$ - J. O. Baggerman ${ }^{1}$ \\ P. R. Broadway ${ }^{1}$ • J. L. Beckett ${ }^{2}$ - M. E. Branine ${ }^{3}$ • B. J. Johnson ${ }^{1}$ (D)
}

Received: 30 June 2015 / Accepted: 24 September 2015 /Published online: 7 October 2015

(C) The Author(s) 2015. This article is published with open access at Springerlink.com

\begin{abstract}
Providing cattle a more bioavailable zinc ( $\mathrm{Zn}$ ) source prior to administering a beta adrenergic agonist $(\beta \mathrm{AA})$ may enhance the metabolic pool of primary nutrients that will influence the magnitude of the $\beta$ AA response. Calffed Holstein steers were supplemented with a $\mathrm{Zn}$ methionine supplement (ZnMet; ZINPRO ${ }^{\circledR}$; Zinpro Corporation, Eden Prairie, MN) for $115 \pm 5$ days prior to harvest along with zilpaterol hydrochloride (ZH; Zilmax ${ }^{\circledR}$; Merck Animal Health, Summit, NJ) for the last 20 days with a 3-day withdrawal to evaluate the effects on growth and carcass performance together with gene and protein expression of skeletal muscle, adipose tissue, and fatty acid composition of polar and neutral lipid depots. Steers $(n=1296$; initial weight $=468.5 \pm$ $0.5 \mathrm{~kg}$ ) were sorted by weight, blocked by harvest date, and randomly assigned to pens $(n=12)$ and treatments: control (90 ppm Zn from $\mathrm{ZnSO}_{4}$ ) and $\mathrm{ZnMet}$ (Control plus $720 \mathrm{mg}$ $\mathrm{Zn}$ from $\mathrm{ZnMet} / \mathrm{hd} / \mathrm{d})$. There were no differences $(P>0.05)$ in growth performance or carcass characteristics. The ZnMet-fed cattle had reduced $(P<0.05)$ abundance of myosin heavy chain (MHC)-IIX, $\beta 1$-adrenergic receptor ( $\beta \mathrm{AR})$, peroxisome proliferator-activated receptor gamma, and stearoylCoA desaturase mRNA in skeletal muscle tissue. The
\end{abstract}

B. J. Johnson

bradley.johnson@ttu.edu

1 Department of Animal and Food Sciences, Texas Tech University, Box 42141, Lubbock, TX 79409-2141, USA

2 Beckett Consulting Services, Fallbrook, CA 92028, USA

3 Zinpro, Eden Prairie, MN 55344, USA

4 Department of Nutrition, Dietetics, and Food Sciences, Utah State University, Logan, UT 84322, USA

5 Department of Animal and Dairy Sciences, Mississippi State University, Starkville, MS 39762, USA
ZnMet cattle had greater $(P<0.05)$ abundance of MHC-II protein, increased MHC-IIA and IIX cross-sectional areas $(P<0.05)$, an increased percentage of MHC-I fibers $(P<0.05)$, and a decreased percentage of MHC-IIX fibers $(P<0.05)$. The combination of ZnMet and $\mathrm{ZH}$ had positive biological effects on musculoskeletal tissue; however, these molecular effects were not significant enough to impact overall feedlot and carcass performance.

Keywords $\beta$-Adrenergic receptor · Myosin heavy chain . Zilpaterol hydrochloride $\cdot$ Zinc methionine

\section{Introduction}

Organic complexes of $\mathrm{Zn}$, such as $\mathrm{Zn}$ methionine (ZnMet) have been shown to possess greater bioavailability than inorganic $\mathrm{Zn}$ forms such as $\mathrm{Zn}$ oxide $(\mathrm{ZnO})$ or $\mathrm{Zn}$ sulfate $\left(\mathrm{ZnSO}_{4}\right)$ [23]. Spears [24] reported that $\mathrm{ZnO}$ and $\mathrm{ZnMet}$ are absorbed to a similar extent but are metabolized differently following absorption. Lambs supplemented with $\mathrm{ZnMet}$ had greater retention of $\mathrm{Zn}$ and nitrogen compared to lambs supplemented with $\mathrm{ZnO}$ [24]. Zinc methionine has been reported to increase growth and feed efficiency in ruminant animals [25]. Furthermore, ZnMet has reportedly improved carcass quality, increasing the percentage of cattle that grade USDA choice [3, $6,21]$.

Zilpaterol hydrochloride $(\mathrm{ZH})$ is a beta adrenergic agonist ( $\beta \mathrm{AA})$, approved for use in cattle under the trade name of Zilmax $^{\circledR}$ (Merck Animal Health, Summit, NJ), and is fed at a rate of $6.8 \mathrm{~g} / \mathrm{ton}(100 \% \mathrm{DM})$ for the last 20 to 40 days of the finishing phase with a 3-day withdrawal prior to slaughter [19]. Zilpaterol $\mathrm{HCl}$ has been documented to improve feed to gain $(\mathrm{F}: \mathrm{G})$, hot carcass weight $(\mathrm{HCW})$, and dressing percentage when administered orally to cattle $[26,29]$. 
Zilpaterol $\mathrm{HCl}$ primarily binds with the beta 2 adrenergic receptor $(\beta 2 \mathrm{AR})$, which is the most predominant beta adrenergic receptor $(\beta A R)$ found in cattle muscle and adipose tissue $[12,13]$. Via a secondary messenger signal cascade event, cyclic adenosine monophosphate (cAMP) is activated thereby resulting in protein accretion and lipid catabolism [12, 13]. The $\beta 2 A R$ potentially has multiple allosteric binding sites for $\mathrm{Zn}[12,27]$. It has been suggested that there are two main binding sites for $\mathrm{Zn}$ on the $\beta \mathrm{AR}$ [28]; one affects the agonist's ability to bind to the receptor, while the other affects the antagonist's ability to bind to the receptor thus increasing cAMP production.

Therefore, providing feedlot cattle with a greater amount of ZnMet prior to administering ZH may provide a greater metabolic pool of primary nutrients that will elicit a greater biological response from the $\mathrm{ZH}$, especially in skeletal muscle tissue. The objective of this study was to determine the effect of supplementing ZnMet (ZINPRO ${ }^{\circledR}$; Zinpro Corporation, Eden Prairie, MN) and $\mathrm{ZH}$ on feedlot growth performance, carcass characteristics, skeletal muscle and adipose tissue gene expression, protein synthesis, and fatty acid composition of calf-fed Holstein steers.

\section{Materials and Methods}

The Institutional Animal Care and Use Committee's approval was not needed for this study, as animals were fed offsite from Texas Tech University at a commercial beef cattle feed yard and harvested at a USDA inspected commercial abattoir [1].

\section{Animals and Management}

Holstein steers $(n=1296 ; 481.5 \pm 0.5 \mathrm{~kg})$ were sourced in southern California and fed in a commercial feed yard prior to study initiation. Initial processing of steers occurred upon arrival, and cattle were subjected to vaccination and management practices in accordance with the feedlot protocols. Initial processing procedures were typical for Holsteins fed in the Southwest USA.

Finishing rations were formulated to meet or exceed the National Research Council [14] requirements for growing and finishing beef cattle. Ingredient composition of the finisher diets is shown in Table 1. Treatment diets were fed ad libitum throughout the study.

Complete ration composition profiles were obtained throughout the study (Table 2). Individual ration samples were sent to Michigan State University (Lancing, MI) for analyses. Ration samples were analyzed for moisture, crude protein (CP), acid detergent fiber (ADF), calcium (Ca), phosphorus $(\mathrm{P})$, potassium $(\mathrm{K})$, and $\mathrm{Zn}$ (Table 2). Pens were observed daily by trained personnel to identify and remove steers with observable signs/symptoms of health and/or lameness issues.
Table 1 Ingredient composition (DM basis) of the experimental finishing diets

\begin{tabular}{lll} 
Bakery waste & 8.17 & 8.30 \\
Steam flaked corn & - & 57.24 \\
Flaked wheat & 60.72 & - \\
Wheat straw & 2.45 & 2.49 \\
Liquid urea & - & 0.64 \\
Dried distillers grain & 9.91 & 13.43 \\
Fat, yellow grease & 5.88 & 4.78 \\
Supplement & 5.33 & 5.46 \\
\hline
\end{tabular}

Diets were formulated to meet or exceed NRC (1996) requirements for growingfinishing beef cattle

Diets contained $6.8 \mathrm{~g} / \mathrm{t}$ zilpaterol hydrochloride (Zilmax: Merck, Summit, NJ) when fed for the final 20 days of the finishing period

${ }^{\text {a }}$ Diet 1 was fed for 174 days, and Diet 2 was fed for 38 days

\section{Experimental Design and Treatments}

Steers were randomized to pens by receiving lot at the time of terminal steroidal implant administration. Each lot was sorted by body weight (BW) to form two pens (one pen/treatment) and blocked by harvest date. A total of 12 pens $(n=108$ head/pen) were utilized and served as experimental unit. Pens $(n=12)$ were randomly assigned to one of two treatments: 1$)$ 90 ppm $\mathrm{Zn}$ from $\mathrm{ZnSO}_{4}$ (CON; $n=6$ pens) or $\mathrm{CON}$ plus $720 \mathrm{mg} / \mathrm{steer} /$ day of Zn from ZINPRO (ZnMet; $n=6$ pens). Treatment diets were administered on the final $115 \pm 5$ days of the finishing period. Zilpaterol $\mathrm{HCl}$ was fed for the final 20 days with a 3-day withdrawal prior to shipping and slaughter. Upon trial initiation, steers were weighed individually (initial BW was reduced by $4 \%$ to represent a standard industry shrink).

\section{Harvest and Carcass Evaluation}

Prior to shipment to the abattoir, steers were weighed by pen on a platform scale (final BW was reduced by $4 \%$ to represent a standard industry shrink). Steers were transported $35 \mathrm{~km}$ to a nearby commercial abattoir and subsequently harvested under USDA-FSIS inspection. Pens of cattle were maintained as lots when presented for harvest.

Carcasses were chilled approximately $36 \mathrm{~h}$ prior to grading. Individual carcass measurements included $\mathrm{HCW}$, dressing percentage (DP), loin muscle area (LMA), and marbling score (MS) and were determined via a digital camera grading system. Yield grade (YG) and quality grade (QG) information was recorded as assigned by USDA graders. Dressing percentage for each pen was calculated as the mean $\mathrm{HCW} /$ mean shrunk ( $4 \%$ pencil shrink) final live weight $\times 100$. 
Table 2 Calculated nutrient and laboratory analysis of diet samples

\begin{tabular}{llll}
\hline & \multicolumn{2}{l}{ Diet designation } & \\
\hline Nutrient & Formulated & CON Finishing $^{\mathrm{a}}$ & ZnMet Finishing $^{\mathrm{b}}$ \\
Dry matter (\%) & 83.5 & 86.60 & 85.40 \\
Crude protein (\%) & 13.3 & 15.80 & 15.70 \\
Acid detergent fiber (\%) & - & 10.00 & 10.90 \\
Neutral detergent fiber, (\%) & - & 19.00 & 20.80 \\
Calcium (\%) & 0.74 & 0.96 & 0.85 \\
Phosphorus (\%) & 0.41 & 0.45 & 0.43 \\
Magnesium (\%) & 0.25 & 0.25 & 0.25 \\
Potassium (\%) & - & 1.02 & 1.00 \\
Sodium (\%) & - & 0.28 & 0.29 \\
Sulfur (\%) & 0.24 & 0.27 & 0.26 \\
Iron (ppm) & - & 317 & 352 \\
Zinc (ppm) & $94 / 160^{\mathrm{c}}$ & 122 & 163 \\
Copper (ppm) & 23 & 28 & 28 \\
Manganese (ppm) & 61 & 77 & 72 \\
Molybdenum (ppm) & - & 1.00 & 1.20 \\
Cobalt (ppm) & 0.70 & 1.40 & 1.30 \\
Selenium (ppm) & 0.40 & 0.60 & 0.59 \\
Iodine (ppm) & 0.80 & 1.10 & 1.14 \\
\hline
\end{tabular}

Samples analyzed by Forage Testing Laboratory, Ithaca, NY, except for Se and I which were analyzed by Michigan State University, Diagnostic Center for Population and Animal Health

${ }^{\text {a }} \mathrm{CON}$ : Control $90 \mathrm{ppm} \mathrm{Zn}$ added from $\mathrm{ZnSO}_{4}$

${ }^{\mathrm{b}}$ ZnMet: Control plus $720 \mathrm{mg} \mathrm{Zn}$ added from $\mathrm{ZINPRO}^{\mathbb{B}}$ zinc methionine

${ }^{\mathrm{c}}$ Formulated $\mathrm{Zn}$ levels for CON and $\mathrm{ZnMet}$ diets, respectively

\section{Collection of Skeletal Muscle and Adipose Tissue}

Steers ( $n=40 ; 20$ steers/treatment) were randomly selected for biochemical analysis of muscle and adipose tissue. Muscle and adipose tissue were collected from the semimembranosus muscle of carcasses within $45 \mathrm{~min}$ of harvest. The pre-rigor semimembranosus tissue sample was cut into thirds. For immunohistochemical analysis, one cut of the samples was placed in a clear frozen section compound (VWR International, Randor, PA), frozen using dry ice-chilled 2methyl-butane and then placed in a cooler of dry ice. The other two cut samples were placed into a whirl-pack for RNA, protein analysis, and fatty acid analysis, flash frozen in liquid nitrogen, and placed in a cooler of dry ice. The adipose tissue was cut in half and placed in a whirl-pack bag for either RNA or protein analysis, flash frozen, and placed in a cooler of dry ice. Samples were then shipped to Texas Tech University for analysis and were subsequently stored in $-80^{\circ} \mathrm{C}$ freezer until analysis.

\section{RNA Isolation and Real-Time Quantitative Reverse Transcription Polymerase Chain Reaction}

Ribonucleic acid from muscle and adipose tissue was isolated with ice-cold buffer containing TRI Reagent ${ }^{\circledR}$ (Sigma, St.
Louis, MO). Approximately $1.5 \mathrm{~g}$ of frozen tissue was homogenized with TRI Reagent ${ }^{(\mathbb{B}}$ at a ratio of $0.5: 1$ grams of tissue to milliliter reagent. The homogenate was then pipetted into two microcentrifuge tubes ( $1 \mathrm{~mL}$ sample per tube), $200 \mu \mathrm{L}$ chloroform was added to each tube, vortexed for $30 \mathrm{~s}$, and incubated for $5 \mathrm{~min}$ The sample was then centrifuged at $15,000 \times g$ for $15 \mathrm{~min}$ separating the sample into three layers. The top supernatant layer was pipetted off and placed into new microcentrifuge tubes. Ice-cold isopropyl alcohol $(250 \mu \mathrm{L})$ was added to the supernatant, shaken, and incubated for $10 \mathrm{~min}$ at $25^{\circ} \mathrm{C}$. The samples were then centrifuged at 15 , $000 \times g$ for $10 \mathrm{~min}$. The supernatant was poured off, the RNA pellet at the bottom of each tube were allowed to dry, and $500 \mu \mathrm{L}$ of $75 \%$ ethanol was added to each tube to rinse and suspend the RNA pellet. Samples were then placed in a $-80{ }^{\circ} \mathrm{C}$ freezer until needed (no longer than 3 months). Samples were then removed from the freezer and thawed on ice. Samples were then centrifuged at $15,000 \times \mathrm{RPM}$ for $10 \mathrm{~min}$, ethanol was poured off, and the pellet was air dried. Nuclease-free water $(30 \mu \mathrm{L})$ was then added to each sample to dissolve the RNA pellet. The concentration of RNA was determined with a spectrophotometer at an absorbance of $260 \mathrm{~nm}$ using a NanoDrop 1000 (NanoDrop products, Wilmington, DE). Samples were then treated with DNAse to remove any DNA contaminants using a DNA-free kit (Life 
Technologies, Grand Island, NY). The RNA was then subjected to reverse transcription to produce cDNA. The cDNA was then used for real-time quantitative reverse transcription-PCR (RT-qPCR) to measure the abundance of AMP-activated protein kinase alpha $(\mathrm{AMPK} \alpha)$, beta 1 adrenergic receptor $(\beta 1 \mathrm{AR})$, beta 2 adrenergic receptor ( $\beta 2 \mathrm{AR})$, and beta 3 adrenergic receptor $(\beta 3 \mathrm{AR})$, myosin heavy chain $(\mathrm{MHC})-\mathrm{I}$, MHC-IIA, MHC-IIX, C-enhancer binding protein beta (CEBP $\beta$ ), G protein-coupled receptor 43 (GPR43), G protein-coupled receptor 41 (GPR41), glucose transporter type 4 (Glut4), peroxisome proliferator-activated receptor gamma (PPAR $\gamma)$, and stearoyl-CoA desaturase (SCD) mRNA relative to the abundance of ribosomal protein subunit 9 (RPS9) mRNA in total RNA isolated from muscle tissue. Real-time qPCR was used to measure the abundance of AMPK $\alpha, \beta 2 A R$, GPR43, GPR41, Glut4, SCD, CEBP $\beta$, and PPAR $\gamma$ mRNA relative to the abundance of RPS9 mRNA in total RNA isolated from adipose tissue. Bovine primers and probes for $\mathrm{AMPK} \alpha, \beta 1 \mathrm{AR}, \beta 2 \mathrm{AR}, \beta 3 \mathrm{AR}$, MHC-I, MHC-IIA, MHC-IIX, GPR43, GPR41, Glut4, SCD, CEBP $\beta$, and PPAR $\gamma$ are presented in Table 3. Assays were performed in the GeneAmp 7900HT Sequence Detection System (Applied Biosystems, Life Technologies) using thermal cycling parameters recommended by the manufacturer ( 40 cycles of $15 \mathrm{~s}$ at $95^{\circ} \mathrm{C}$ and $1 \mathrm{~min}$ at $60^{\circ} \mathrm{C}$ ).

\section{Protein Extraction, Western Blots, and SDS-PAGE Gel Electrophoresis}

Protein from muscle was isolated with whole muscle extraction buffer (WMEB; $2 \%$ sodium dodecyl sulfate, $10 \mathrm{mM}$ phosphate, $\mathrm{pH}$ 7.0). Adipose tissue protein was isolated with an ice-cold buffer containing tissue protein extraction reagent (T-PER; Fisher Scientific, Fair Lawn, NJ), protein inhibitor (Roche, Branchburg, NJ), and $2 \mathrm{mM} \mathrm{Na}_{3} \mathrm{VO}_{4}$ (Fisher Scientific) at a 1:5 ratio. The homogenized samples were centrifuged at $15,000 \times \mathrm{g}$ for $15 \mathrm{~min}$, separating the sample into three layers. The middle supernatant layer was pipetted off and placed into microcentrifuge tubes. The protein samples were then diluted with either T-PER or WMEB to determine protein concentration using the Pierce ${ }^{\mathrm{TM}} \mathrm{BCA}^{\mathrm{TM}}$ protein assay (Thermo Fisher Scientific, Fairlawn, NJ). Protein concentration was then determined using a NanoDrop 1000 spectrophotometer at $562 \mathrm{~nm}$. All samples were then diluted to the same concentration. Modified Wang's tracking dye was added to western blot samples, and MHC tracking dye was added to sodium dodecyl sulfate polyacrylamide gel electrophoresis (SDS-PAGE) samples. Samples were denatured with $\beta$ mercaptoethanol and incubated for 2 min at $95{ }^{\circ} \mathrm{C}$. Samples for western blots were then loaded onto Novex 4-12 \% BisTris gels (Invitrogen, Grand Island, NY), and protein was separated by gel electrophoresis. The gels were run for approximately $35 \mathrm{~min}$ at $165 \mathrm{~V}$ and $27 \mathrm{~mA}$. Proteins were transferred onto a nitrocellulose membrane (Invitrogen) for 7 min. Following transfer, the membrane was incubated with non-fat dry milk (BIO RAD, Hercules, CA), $10 \% 10 \times$ trisbuffered saline (TBS) in NanoPure water for $1 \mathrm{~h}$ at $25{ }^{\circ} \mathrm{C}$ to block non-specific antibody binding. The blocking solution was then removed from the membrane. The appropriate primary antibodies 1:1000 $\alpha$-beta $1 \mathrm{AR}$, rabbit, $\operatorname{IgG}\left(\right.$ abcam $^{\mathbb{B}}$, Cambridge, MA); 1:1000 $\alpha$-beta 2 AR, goat, IgG (abcam); and 1:1000 $\alpha$-beta $3 \mathrm{AR}$, goat, IgG (abcam) were mixed into 1 $\times$ TBS-Tween solution, added to the membrane and allowed to incubate for $2 \mathrm{~h}(\beta 1 \mathrm{AR})$ or $1 \mathrm{~h}(\beta 2 \mathrm{AR}$ and $\beta 3 \mathrm{AR})$ at $25^{\circ} \mathrm{C}$. The membrane was then rinsed three times for $10 \mathrm{~min}$ in TBSTween. The appropriate Alexa fluorescent antibodies goat $\alpha$ rabbit, IgG, Alexa-Fluor 633 (Invitrogen) and donkey $\alpha$-goat, IgG, Alexa-Fluor 633 (Invitrogen) were then added at a dilution of 1:2000 in TBS-Tween to the membrane and incubated for $1 \mathrm{~h}$ at $25^{\circ} \mathrm{C}$ in the absence of light. The membranes were then rinsed three times for $10 \mathrm{~min}$ in TBS-Tween in unlighted conditions. The membranes were then dried and visualized using the Imager Scanner II and ImageQuant TL programs. Densitometry measurements were made on the bands corresponding to $\beta 1 \mathrm{AR}, \beta 2 \mathrm{AR}$, and $\beta 3 \mathrm{AR}$ using a molecular weight standard for reference (Precision Plus Protein ${ }^{\text {TM }}$ All Blue Standards; BIO RAD).

For SDS-PAGE, $6 \%$ acrylamide separating gels with $4 \%$ acrylamide stacking gels were made and set at $4{ }^{\circ} \mathrm{C}$ for $4-24 \mathrm{~h}$. Samples were then loaded onto the gels, and protein was separated by gel electrophoresis. The gels were run for approximately $72 \mathrm{~h}$ at $100 \mathrm{~V}$. The gel was placed in $300 \mathrm{~mL}$ Coomassie $^{\circledR}$ Fluor Orange (Life Technologies) for $30 \mathrm{~min}$ at $25^{\circ} \mathrm{C}$ in an opaque container. The Coomassie Fluor Orange was drained off the gel, and the gel was briefly rinsed in $7.5 \%$ acetic acid followed by NanoPure water. The gels were then visualized using the Imager Scanner II and ImageQuant TL programs. Densitometry measurements were made on the bands corresponding to MHC-II and MHC-I.

\section{Immunohistochemical Analysis}

Twenty-four hours prior to sectioning, embedded muscle samples were moved from -80 to a $-20{ }^{\circ} \mathrm{C}$ freezer to thaw. Muscle fiber distribution, area, $\beta$-adrenergic receptor, and satellite cell abundance were determined on $10-\mu \mathrm{m}$ thick cross sections. The sections were cut at $-20{ }^{\circ} \mathrm{C}$ using a Leica CM1950 cryostat (Lieca Biosystems, Buffalo Grove, IL) from the embedded muscle samples. The sections were then mounted on positively charged glass slides (five slides per sample/three cryosections per slide; Superfrost Plus; VWR International). Cryosections were fixed using $4 \%$ paraformaldehyde (Thermo Fisher Scientific) for $10 \mathrm{~min}$ at $25^{\circ} \mathrm{C}$ followed by two brief rinses and a single 5-min rinse in phosphate buffered saline (PBS). Cryosections were incubated with $5 \%$ horse serum (Invitrogen), $2 \%$ bovine serum albumin (MP 
Table 3 Sequence of bovinespecific PCR primers and TaqMan probes to be used for determination of expression of mRNA of AMPK $\alpha$, MHC-I, MHC-IIA, MHC-IIX, $\beta 1 \mathrm{AR}$, $\beta 2 \mathrm{AR}, \beta 3 \mathrm{AR}, \mathrm{CEBP} \beta, \mathrm{GPR} 43$, GPR41, Glut4, PPAR $\gamma$, SCD, and RPS9

\begin{tabular}{|c|c|}
\hline Primer & Sequence $\left(5^{\prime}\right.$ to $\left.3^{\prime}\right)$ \\
\hline \multicolumn{2}{|c|}{ AMPk $\alpha$ (accession \# NM_001109802) } \\
\hline Forward & ACCATTCTTGGTTGCTGAAACTC \\
\hline Reverse & CACCTTGGTGTTTGGATTTCTG \\
\hline TaqMan probe & 6FAM-CAGGGCGCGCCATACCCTTG-TAMRA \\
\hline \multicolumn{2}{|c|}{ MHC-I (accession no. AB059400) } \\
\hline Forward & СССАСТТСТСССТGАТССАСТАС \\
\hline Reverse & TTGAGCGGGTCTTTGTTTTTCT \\
\hline TaqMan probe & 6FAM-CCGGCACGGTGGACTACAACATCATAG-TAMRA \\
\hline \multicolumn{2}{|c|}{ MHC-IIA (accession no. AB059398) } \\
\hline Forward & GCAATGTGGAAACGATCTCTAAAGC \\
\hline Reverse & GCTGCTGCTCCTCCTCCTG \\
\hline TaqMan probe & 6FAM-TCTGGAGGACCAAGTGAACGAGCTGA-TAMRA \\
\hline \multicolumn{2}{|c|}{ MHC-IIX (accession no. AB059399) } \\
\hline Forward & GGCCCACTTCTCCCTCATTC \\
\hline Reverse & CCGACCACCGTCTCATTCA \\
\hline TaqMan probe & 6FAM-CGGGCACTGTGGACTACAACATTACT-TAMRA \\
\hline \multicolumn{2}{|c|}{$\beta 1 \mathrm{AR}$ (accession no. AF188187) } \\
\hline Forward & GTGGGACCGCTGGGAGTAT \\
\hline Reverse & TGACACACAGGGTCTCAATGC \\
\hline TaqMan probe & 6FAM-CTCCTTCTTCTGCGAGCTCTGGACCTC-TAMRA \\
\hline \multicolumn{2}{|c|}{ ß2AR (accession no. NM_174231) } \\
\hline Forward & CAGCTCCAGAAGATCGACAAATC \\
\hline Reverse & CTGCTCCACTTGACTGACGTTT \\
\hline TaqMan probe & 6FAM-AGGGCCGCTTCCATGCCC-TAMRA \\
\hline \multicolumn{2}{|c|}{ ß3AR (accession no. X85961) } \\
\hline Forward & AGGCAACCTGCTGGTAATCG \\
\hline Reverse & GTCACGAACACGTTGGTCATG \\
\hline TaqMan probe & 6FAM-CCCGGACGCCGAGACTCCAG-TAMRA \\
\hline \multicolumn{2}{|c|}{ CEBP $\beta$ (accession no. NM_176788) } \\
\hline Forward & CCAGAAGAAGGTGGAGCAACTG \\
\hline Reverse & TCGGGCAGCGTCTTGAAC \\
\hline TaqMan probe & 6FAM-CGCGAGGTCAGCACCCTGC-TAMRA \\
\hline \multicolumn{2}{|c|}{ GPR43 (accession no. FJ562212) } \\
\hline Forward & GGCTTTCCCCGTGCAGTA \\
\hline Reverse & ATCAGAGCAGCCATCACTCCAT \\
\hline TaqMan probe & 6FAM-AAGCTGTCCCGCCGGCCC-TAMRA \\
\hline \multicolumn{2}{|c|}{ GPR41 (accession no. FJ562213) } \\
\hline Forward & TGCTCCTCAGCACCCTGAA \\
\hline Reverse & TTGGAACCCAGATGATGAGAAA \\
\hline TaqMan probe & 6FAM-TCCTGCGTCGACCCCCTTGTCTAC-TAMRA \\
\hline \multicolumn{2}{|c|}{ Glut4 (accession no. D63150) } \\
\hline Forward & CCTCGGCAGCGAGTCACT \\
\hline Reverse & AAACTGCAGGGAGCCAAGAA \\
\hline TaqMan probe & 6FAM-CCTTGGTCCTTGGCGTATTCTCCGC-TAMRA \\
\hline \multicolumn{2}{|c|}{ PPAR $\gamma$ (accession no. NM_181024) } \\
\hline Forward & ATCTGCTGCAAGCCTTGGA \\
\hline Reverse & TGGAGCAGCTTGGCAAAGA \\
\hline TaqMan probe & 6FAM-CTGAACCACCCCGAGTCCTCCCAG-TAMRA \\
\hline \multicolumn{2}{|c|}{ SCD (accession no. AB075020) } \\
\hline Forward & TGCCCACCACAAGTTTTCAG \\
\hline
\end{tabular}


Table 3 (continued)

\begin{tabular}{ll}
\hline Primer & Sequence (5' to 3') \\
\hline Reverse & GCCAACCCACGTGAGAGAAG \\
TaqMan probe & 6FAM-CCGACCCCCACAATTCCCG-TAMRA \\
RPS9 (accession no. DT860044) & \\
Forward & GAGCTGGGTTTGTCGCAAAA \\
Reverse & GGTCGAGGCGGGACTTCT \\
TaqMan probe & 6FAM-ATGTGACCCCGCGGAGACCCTTC-TAMRA \\
\hline
\end{tabular}

AMPK $\alpha$ AMP-activated protein kinase alpha, $M H C$-I myosin heavy chain-I, MHC-IIA myosin heavy chain-IIA, $M H C$-IIX myosin heavy chain-IIX, $\beta 1 A R$ beta 1 adrenergic receptor, $\beta 2 A R$ beta 2 adrenergic receptor, $\beta 3 A R$ beta 3 adrenergic receptor, $C E B P \beta$ C-enhancer binding protein beta, GPR 43 G-protein coupled receptor $43, G P R 41$ G-protein coupled receptor 41, Glut4 glucose transporter type 4, $P P A R \gamma$ peroxisome proliferator-activated receptor gamma, SCD stearoyl-CoA desaturase and RPS9 ribosomal protein S9

Biomedical, Solon, $\mathrm{OH}$ ), and $0.2 \%$ Triton-X100 (Thermo Fisher Scientific) in PBS for $30 \mathrm{~min}$ at $25^{\circ} \mathrm{C}$ to block nonspecific antibody binding. Cryosections were then incubated for $1 \mathrm{~h}$ at $25^{\circ} \mathrm{C}$ in the following primary antibodies: slide 1 , 1:100 $\alpha$-dystrophin, rabbit, IgG (Thermo Scientific); 1:100 supernatant anti-MHC type 1, IgG2b (BA-D5; Developmental Studies Hybridoma Bank, University of Iowa, Iowa City, IA); and supernatant anti-MHC (all but type IIX IgG1; BF-35, Developmental Studies Hybridoma Bank); slide 2, 1:750 $\alpha$-beta 1 AR, rabbit, IgG (abcam); 1:750 $\alpha$-beta 2 AR, chicken, IgY (abcam); 1:500 $\alpha$-beta 3 AR, goat, IgG (abcam); slide 3, 1:10 supernatant anti-paired box protein 7 (Pax7), mouse $\alpha$-chicken (Developmental Studies Hybridoma Bank); 1:100 myogenic factor 5 (Myf-5), rabbit, IgG (Santa Cruz Biotechnology, Dallas, TX). Slides were then rinsed three times for $5 \mathrm{~min}$ in PBS. Cryosections were incubated for $30 \mathrm{~min}$ at $25^{\circ} \mathrm{C}$ in opaque boxes in the following secondary antibodies: slide $1,1: 1000$ goat $\alpha$-rabbit, IgG, Alexa-Fluor 488 (Invitrogen); 1:1000 goat $\alpha$-mouse, IgG1, Alexa-Fluor 546 (Invitrogen); 1:1000 goat $\alpha$-mouse, IgG2b, Alexa-Fluor 633 (Invitrogen); slide 2, 1:1000 goat $\alpha$-chicken, IgY, H \& L, Alexa-Fluor 488 (abcam); 1:1000 donkey $\alpha$-rabbit, IgG, Alexa-Fluor 546 (Invitrogen); 1:1 000 donkey $\alpha$-goat, IgG, Alexa-Fluor 633 (Invitrogen); slide 3, 1:1000 goat $\alpha$-rabbit, IgG, Alexa-Fluor 488 (Invitrogen); 1:1000 goat $\alpha$-mouse, IgG1, Alexa-Fluor 546 (Invitrogen). Slides were then rinsed three times for $5 \mathrm{~min}$ in PBS. Finally, cryosections were incubated in $1 \mu \mathrm{g} / \mathrm{mL} \mathrm{4',6-diamidino-2-phenylindole} \mathrm{(DAPI,}$ Thermo Fisher Scientific) for 1 min followed by two brief PBS rinses. Slides were cover-slipped with mounting media (Aqua Mount; Lerner Laboratories, Pittsburgh, PA) and thin glass cover slips (VWR International), and dried at $4{ }^{\circ} \mathrm{C}$ for $24 \mathrm{~h}$. All slides were imaged within $48 \mathrm{~h}$ of staining.

The slides were imaged at $\times 200$ working difference magnification using an inverted fluorescence microscope (Nikon Eclipse, Ti-E; Nikon Instruments Inc., Mellville, NY) equipped with a UV light source (Nikon Intensilight Inc.; CHGFIE). The images were captured by a CoolSnap $\mathrm{ES}^{2}$ monochrome camera and artificially colored and analyzed using the NIS Elements ${ }^{\circledR}$ Imaging software.

Five random images were taken of cryosections from each slide of the semimembranosus tissue. All MHC type I, IIA, and IIX muscle fibers in each image were identified and expressed as a percentage of the total number of muscle fibers. The cross-sectional area of each fiber in each image was measured using the NIS Elements software (Nikon Instruments Inc.) and expressed on a square millimeter basis. The total number of DAPI-stained cells in each image were enumerated to determine the nuclear density on a per square millimeter basis. All $\beta A R$, Pax7, Myf5, and, Pax7+Myf5 satellite cells were identified on the respective slides stained for them, counted, and densities are reported on a square $\mathrm{mm}$ basis. Beta-adrenergic receptors were classified as $\beta$ AR or internalized $\beta A R$. Classification was determined by the location of the stained receptors on the fiber cross-section. Receptors located on sarcolemma were considered normal $\beta A R$, and the receptors located within the fiber cross-section were considered internalized $\beta$ AR.

\section{Fatty Acid Analysis}

Fatty acids (FA) were determined for the polar (PL) and neutral lipids (NL) of each muscle tissue sample [9]. Muscle tissue was cubed, flash-frozen in liquid nitrogen, and homogenized into fine powder. All tissue homogenates were stored at $-80{ }^{\circ} \mathrm{C}$ until subsequent analysis. Total lipids were extracted from 0.5 -g tissue homogenates by a chloroform:methanol extraction [2]. Extracted lipids were fractionated using a Resprep $^{\circledR}$ silica gel cartridge (Restek Corporation, Bellefonte, PA), where NL were initially eluted with chloroform, and PL were subsequently eluted with methanol [7]. Fatty acids of the NL were saponified and derivatized to fatty acid methyl esters (FAME) using sodium methoxide in methanol [10]. Saponification and derivatization of PL FA was carried out with methanolic potassium hydroxide [11]. Tridecanoic acid methyl ester (CAS\# 1731-88-0, Sigma- 
Aldrich) was used as the internal standard during derivatization. Analysis of FAME was carried out by an Agilent Technologies (Santa Clara, CA) 7890 gas chromatograph equipped with an HP-88 capillary column $(30 \mathrm{~m} \times 250 \mu \mathrm{m} \times$ $0.2 \mu \mathrm{m}$; Agilent Technologies, Santa Clara, CA) and a flame ionization detector. Identity of FAME was determined by comparison with authentic FAME standards (Supelco ${ }^{\circledR} 37$ Component FAME Mix, Sigma-Aldrich, St Louis, MO) and quantified by an internal standard calibration. Individual FA were calculated as milligram per gram of muscle tissue. FA were added to calculate the total FA concentration (mg/g muscle tissue) of each fraction and the entire FA composition. Percentages of FA were determined by dividing the individual FA concentration ( $\mathrm{mg} / \mathrm{g}$ muscle tissue) by the corresponding total FA concentration ( $\mathrm{mg} / \mathrm{g}$ muscle tissue) then multiplying by 100 . Percentages of NL and PL fractions were calculated by dividing the lipid fraction concentrations ( $\mathrm{mg} / \mathrm{g}$ muscle tissue) by the total FA concentration ( $\mathrm{mg} / \mathrm{g}$ muscle tissue).

\section{Statistical Analysis}

Performance and carcass data were analyzed using the GLIMMIX procedure of SAS (v.9.3, SAS Institute; Carey, NC). The model included block as a random effect, and treatment served as a fixed effect. Pen served as the experimental unit for feedlot performance and carcass characteristics. Initial weight was used as a covariate. Treatment means were separated using the LSMEANS procedure with PDIFF option and considered different at $P<0.05$. Tendencies for differences among treatment means were declared when $0.05>P \leq 0.10$. Yield grade and quality grade distributions were analyzed using the FREQUENCY procedure of SAS using the chisquare option.

For all biochemical analysis, data were analyzed using the GLIMMIX procedure of SAS (v.9.3, SAS Institute; Carey, $\mathrm{NC}$ ). The model included treatment as the fixed effect, steer served as the experimental unit, and the Kenward-Roger adjustment was used to correct degrees of freedom. Means were separated using the LSMEANS procedure with the PDIFF option and considered different when $P \leq 0.05$. Tendencies for differences among treatment means were declared when $0.05>P \leq 0.10$.

\section{Results and Discussion}

There were no differences $(P>0.05$; Table 4$)$ in starting and final weights, dry matter intake (DMI), average daily gain (ADG), and feed to gain ratios. Spears [24] reported differences in weight of heifers supplemented with $\mathrm{ZnO}$ or $\mathrm{ZnMet}$ when compared to control. However, when $\mathrm{ZnO}$ and $\mathrm{ZnMet}$ were supplemented to lambs, ADG and $F: G$ were improved with $\mathrm{Zn}$ supplementation [24]. Zinc methionine has been
Table 4 Effect of zinc methionine complex in combination with zilpaterol hydrochloride on growth performance of calf-fed Holstein steers

\begin{tabular}{lllrl}
\hline & CON $^{\mathrm{a}}$ & ZnMet $^{\mathrm{b}}$ & \multicolumn{1}{c}{ SEM $^{\mathrm{c}}$} & $P$ value \\
\hline Start (wt, kg) & 482 & 481 & 3.54 & 0.837 \\
Final (wt, kg) & 618 & 615 & 4.81 & 0.634 \\
Pen start (wt, kg) & 52057 & 51974 & 382.63 & 0.838 \\
Pen final (wt, kg) & 65539 & 65425 & 1041.42 & 0.916 \\
Mortality, $n$ & 3 & 1 & 0.88 & 0.309 \\
DOF & 114 & 114 & 0.45 & 0.602 \\
DMI (kg) & 8.38 & 8.40 & 0.04 & 0.666 \\
ADG (kg) & 1.14 & 1.16 & 0.04 & 0.750 \\
F:G & 7.61 & 7.34 & 0.33 & 0.465 \\
G:F & 0.13 & 0.13 & 0.01 & 0.638 \\
\hline
\end{tabular}

${ }^{\text {a }} \mathrm{CON}$ : Control $90 \mathrm{ppm} \mathrm{Zn}$ added from $\mathrm{ZnSO}_{4}$ ( $n=6$ pens).

${ }^{\mathrm{b}} \mathrm{ZnMet}$ : Control plus $720 \mathrm{mg} \mathrm{Zn}$ added from ZINPRO ${ }^{\circledR}$ zinc methionine ( $n=6$ pens).

${ }^{\mathrm{c}}$ Pooled standard error of the mean

reported to increase rate of gain and feed efficiency of heifers [25]. Greene [3] and Rust [21] reported no difference in gain or feed efficiency when steers were supplemented $\mathrm{ZnO}$ or ZnMet. In a more recent study, the addition of $\mathrm{Zn}$ on ADG in heifers was unaffected [6]. However, there was an interaction between $\mathrm{Zn}$ and implant when $\mathrm{Zn}$ was supplemented to heifers and steers [6]. In the heifers, ADG was $26 \%$ greater in non-implanted heifers fed with ZnMet than implanted heifers fed with $\mathrm{ZnMet}$ [6]. When $\mathrm{ZnSO}_{4}$ was the supplemented $\mathrm{Zn}$ source, it did not have an effect on $\mathrm{ADG}$, and the implanted heifers had a greater $\mathrm{ADG}$ regardless of $\mathrm{ZnSO}_{4}$ supplementation [6]. When steers were implanted and supplemented a $\mathrm{Zn}$ source, the results were different [6]. Implant improved ADG in steers fed with a control diet or supplemented with $\mathrm{ZnSO}_{4}$, but did not affect ADG of implanted steers supplemented with ZnMet [6]. Furthermore, in the current study, there was no difference $(P>0.05$; Table 5$)$ in HCW, DP, LMA, MS, and YG between the ZnMet and CON cattle. There were no differences between YG and QG distributions $(P>0.05$; Table 6). Greene et al. [3] reported that ZnMet increased the percent of kidney, pelvic and heart fat, MS, and overall QG and tended to increase backfat thickness. Rust [21] reported that steers supplemented with ZnMet graded $47 \%$ USDA Choice compared to control at $37 \%$, and Greene et al. [3] reported ZnMet steers graded $79 \%$ USDA Choice compared to control at $57 \%$ and $\mathrm{ZnO}$ at $40 \%$. While our distributions were not significant $(P=$ $0.134), 4 \%$ of ZnMet supplemented steers graded USDA Prime compared to the $1 \%$ of CON. Huerta et al. [6] reported that heifers supplemented ZnMet graded $70 \%$ USDA Choice compared to $50 \%$ USDA Choice in control heifers and $30 \%$ USDA Choice in $\mathrm{ZnSO}_{4}$ heifers. However, there were no differences in carcass grades or other carcass characteristics 
Table 5 Effect of zinc methionine complex in combination with zilpaterol hydrochloride on carcass characteristics of calf-fed Holstein steers

\begin{tabular}{lllll}
\hline & $\mathrm{CON}^{\mathrm{a}}$ & ZnMet $^{\mathrm{b}}$ & SEM $^{\mathrm{d}}$ & $P$ value \\
\hline HCW (kg) & 389 & 388 & 2.75 & 0.794 \\
Dress (\%) & 62.9 & 63.0 & 0.53 & 0.858 \\
Marbling & 475 & 487 & 6.83 & 0.139 \\
LMA $\left(\mathrm{cm}^{2}\right)$ & 82.35 & 81.83 & 0.47 & 0.317 \\
USDA yield grade & 2.8 & 2.8 & 0.03 & 0.835 \\
\hline
\end{tabular}

${ }^{\text {a }} \mathrm{CON}$ : Control $90 \mathrm{ppm} \mathrm{Zn}$ added from $\mathrm{ZnSO}_{4}$ ( $n=6$ pens)

${ }^{\mathrm{b}} \mathrm{ZnMet}$ : Control plus $720 \mathrm{mg} \mathrm{Zn}$ added from $\mathrm{ZINPRO}^{\circledR}$ zinc methionine ( $n=6$ pens)

${ }^{\mathrm{c}}$ Marbling score $300=$ slight; $400=$ small; 500=modest

${ }^{\mathrm{d}}$ Pooled standard error of the mean

of steers supplemented with $\mathrm{ZnMet}$ or $\mathrm{ZnSO}_{4}$ [6]. To our knowledge, no other published literature has evaluated the effects of ZnMet supplementation and $\mathrm{ZH}$ feeding in beef cattle.

In the semimembranosus tissue, ZnMet cattle contained a greater abundance of MHC-I mRNA $(P<0.05$; Table 7) and tended to have a greater abundance of $\beta 2 \mathrm{AR}$ mRNA $(P<0.10$; Table 7). The ZnMet-supplemented cattle had a lower $(P<0.05)$ abundance of MHC-IIX and $\beta 1 \mathrm{AR}$ mRNA. Peroxisome proliferator-activated receptor gamma and SCD mRNA abundance were greater $(P<0.05)$ in CON cattle. There were no changes $(P>0.05$; Table 7$)$ in AMPK $\alpha$, MHC-IIA, $\beta 2 \mathrm{AR}, \beta 3 \mathrm{AR}, \mathrm{CEBP} \beta$, GPR 43, GPR 41 , and Glut4 mRNA between treatments. Knobel [8] reported that ZH increased MHC-IIX in the gluteus medius supporting the results seen in our CON group. In data collected from our laboratory in bovine satellite cells treated with $0 \mu \mathrm{M} \mathrm{ZH}$ and $0 \mu \mathrm{M} \mathrm{Zn}, 10 \mu \mathrm{M} \mathrm{ZH}, 1 \mu \mathrm{M} Z \mathrm{Zn}$, or $10 \mu \mathrm{M} \mathrm{ZH}$ and $1 \mu \mathrm{M} \mathrm{Zn}$,

Table 6 Effect of zinc methionine complex in combination with zilpaterol hydrochloride on USDA quality and yield grade of calf-fed Holstein steers

\begin{tabular}{lrrrr}
\hline Grade, \% of carcasses & CON $^{\mathrm{a}}$ & ZnMet $^{\mathrm{b}}$ & SEM $^{\mathrm{c}}$ & $P$ value \\
\hline Prime & 1.30 & 4.35 & 1.70 & 0.134 \\
Choice & 78.39 & 76.07 & 2.66 & 0.423 \\
Select & 19.78 & 18.75 & 2.38 & 0.682 \\
No roll & 0.52 & 0.82 & 0.32 & 0.396 \\
Yield grade 1 & 6.13 & 3.96 & 1.97 & 0.322 \\
Yield grade 2 & 57.90 & 62.40 & 2.74 & 0.161 \\
Yield grade 3 & 34.96 & 33.13 & 3.70 & 0.642 \\
Yield grade 4 & 1.20 & 1.20 & 0.48 & 1.000 \\
\hline
\end{tabular}

${ }^{\text {a }} \mathrm{CON}$ : Control $90 \mathrm{ppm} \mathrm{Zn}$ added from $\mathrm{ZnSO}_{4}$ ( $n=6$ pens)

${ }^{\mathrm{b}} \mathrm{ZnMet}$ : Control plus $720 \mathrm{mg} \mathrm{Zn}$ added from ZINPRO ${ }^{\mathbb{E}}$ zinc methionine ( $n=6$ pens)

${ }^{\mathrm{c}}$ Pooled standard error of the mean
Table 7 Effect of zinc methionine complex in combination with zilpaterol hydrochloride on relative mRNA concentrations of AMPK $\alpha$, MHC-I, MHC-IIA, MHC-IIX, $\beta 1 \mathrm{AR}, \beta 2 \mathrm{AR}, \beta 3 \mathrm{AR}, \mathrm{CEBP} \beta$, GPR 43 , GPR41, Glut4, PPAR $\gamma$, and SCD genes in semimembranosus tissue

\begin{tabular}{lrrrr}
\hline Gene $^{\mathrm{a}}$ & $\mathrm{CON}^{\mathrm{b}}$ & ZnMet $^{\mathrm{c}}$ & SEM $^{\mathrm{d}}$ & $P$ value \\
\hline AMPk $\alpha$ & 1.746 & 1.613 & 0.207 & 0.525 \\
MHC-I & 0.649 & 1.025 & 0.166 & 0.030 \\
MHC-IIA & 2.517 & 2.208 & 0.438 & 0.485 \\
MHC-IIX & 1.514 & 1.085 & 0.165 & 0.013 \\
$\beta 1 \mathrm{AR}$ & 7.163 & 3.101 & 1.457 & 0.008 \\
$\beta 2 \mathrm{AR}$ & 0.894 & 1.282 & 0.194 & 0.053 \\
$\beta 3 \mathrm{AR}$ & 33.133 & 41.718 & 9.752 & 0.397 \\
CEBP $\beta$ & 5.670 & 4.838 & 1.157 & 0.476 \\
GPR43 & 2.391 & 0.873 & 1.292 & 0.247 \\
GPR41 & 38.694 & 38.257 & 16.807 & 0.979 \\
Glut4 & 1.035 & 1.123 & 0.095 & 0.363 \\
PPAR $\gamma$ & 3.020 & 1.749 & 0.540 & 0.024 \\
SCD & 9.745 & 2.303 & 3.052 & 0.019 \\
\hline
\end{tabular}

$A M P K \alpha$ AMP-activated protein kinase alpha, $M H C-I$ myosin heavy chain-I, MHC-IIA myosin heavy chain-IIA, MHC-IIX myosin heavy chain-IIX, $\beta 1 A R$ beta 1 adrenergic receptor, $\beta 2 A R$ beta 2 adrenergic receptor, $\beta 3 A R$ beta 3 adrenergic receptor, $C E B P \beta \mathrm{C}$-enhancer binding protein beta, GPR43 G-protein coupled receptor 43, GPR41 G-protein coupled receptor 41, Glut4 glucose transporter type 4, $P P A R \gamma$ peroxisome proliferator-activated receptor gamma, $S C D$ stearoyl-CoA desaturase

${ }^{a}$ Relative abundance of the AMPK $\alpha$, MHC-I, MHC-IIA, MHC-IIX, $\beta 1 \mathrm{AR}, \beta 2 \mathrm{AR}, \beta 3 \mathrm{AR}, \mathrm{CEBP} \beta$, GPR43, GPR41, Glut4, PPAR $\gamma$, and SCD genes were normalized with the RPS9 endogenous control by using the change in cycle threshold $(\Delta \mathrm{CT})$

${ }^{\mathrm{b}} \mathrm{CON}$ : Control $90 \mathrm{ppm} \mathrm{Zn}$ added from $\mathrm{ZnSO}_{4}$ ( $n=20$ steers)

${ }^{\mathrm{c}}$ ZnMet: Control plus $720 \mathrm{mg} \mathrm{Zn}$ added from $\mathrm{ZINPRO}^{\circledR}$ zinc methionine ( $n=20$ steers)

${ }^{\mathrm{d}}$ Pooled standard error of the mean

we discovered that the combination of $\mathrm{Zn}$ and $\mathrm{ZH} 96 \mathrm{~h}$ posttreatment decreased MHC-IIX and tended to increase MHC-I mRNA abundance [5] reflecting the results of this trial. In bovine satellite cell culture work, the addition of ractopamine $\mathrm{HCl}(\mathrm{RH})$ and $\mathrm{Zn}$ had no effect on $\beta 1 \mathrm{AR}, \beta 2 \mathrm{AR}, \mathrm{AMPK} \alpha$, IGF-1, MHC-I, MHC-IIA, and MHC-IIX mRNA abundance [4]. Ractopamine $\mathrm{HCl}$ is another $\beta \mathrm{AA}$ used in beef and pork production. Analysis of the adipose tissue in this study revealed a greater abundance of Glut 4 mRNA in CON cattle $(P<0.05$; Table 8$)$ when compared to ZnMet. Analysis of AMPK $\alpha, \beta 2 A R$, CEBP $\beta$, GPR 43, GPR $41, \operatorname{PPAR} \gamma$, and SCD revealed no differences $(P>0.05)$ between treatments. Oh and Choi [15] reported an increase in PPAY $\gamma 2$ mRNA expression in bovine intramuscular adipocytes when $\mathrm{Zn}$ sources were added to the differentiation media at a concentration of 50 and $100 \mu \mathrm{M}$.

No differences were detected $(P>0.05$; Table 9$)$ in $\beta 1 \mathrm{AR}$, $\beta 2 \mathrm{AR}$, and $\beta 3 \mathrm{AR}$ protein abundance between treatments in the semimembranosus tissue. There were also no differences 
Table 8 Effect of zinc methionine complex in combination with zilpaterol hydrochloride on relative mRNA concentrations of AMPK $\alpha$, $\beta 2 \mathrm{AR}, \mathrm{CEBP} \beta$, GPR 43, Glut4, PPAR $\gamma$, and SCD genes in subcutaneous adipose tissue

\begin{tabular}{lrrrr}
\hline Gene $^{\mathrm{a}}$ & \multicolumn{1}{c}{$\mathrm{CON}^{\mathrm{b}}$} & ZnMet $^{\mathrm{c}}$ & \multicolumn{1}{c}{ SEM $^{\mathrm{d}}$} & $P$ value \\
\hline AMPk $\alpha$ & 0.944 & 0.895 & 0.130 & 0.708 \\
$\beta 2 \mathrm{AR}$ & 0.947 & 0.866 & 0.263 & 0.758 \\
CEBP $\beta$ & 0.467 & 0.675 & 0.231 & 0.373 \\
GPR43 & 210.230 & 356.230 & 169.240 & 0.400 \\
Glut4 & 0.843 & 0.545 & 0.136 & 0.035 \\
PPAR $\gamma$ & 0.895 & 0.999 & 0.176 & 0.558 \\
SCD & 2.358 & 2.355 & 1.016 & 0.997 \\
\hline
\end{tabular}

$A M P K \alpha$ AMP-activated protein kinase alpha, $\beta 2 A R$ beta 2 adrenergic receptor, $C E B P \beta \mathrm{C}$-enhancer binding protein beta, GPR43 G-protein coupled receptor 43, GPR41 G-protein coupled receptor 41, Glut4 glucose transporter type 4, $P P A R \gamma$ peroxisome proliferator-activated receptor gamma, $S C D$ stearoyl-CoA desaturase

${ }^{a}$ Relative abundance of the AMPK $\alpha, \beta 2 \mathrm{AR}, \operatorname{CEBP} \beta$, GPR43, GPR41, Glut4, PPAR $\gamma$, and SCD genes were normalized with the RPS9 endogenous control by using the change in cycle threshold $(\triangle \mathrm{CT})$

${ }^{\mathrm{b}} \mathrm{CON}$ : Control $90 \mathrm{ppm} \mathrm{Zn}$ added from $\mathrm{ZnSO}_{4}$ ( $n=20$ steers)

${ }^{\mathrm{c}}$ ZnMet: Control plus $720 \mathrm{mg} \mathrm{Zn}$ added from ZINPRO ${ }^{\circledR}$ zinc methionine $(n=20$ steers $)$

${ }^{\mathrm{d}}$ Pooled standard error of the mean

$(P>0.05$; Table 9) in $\beta 2 \mathrm{AR}$ and $\beta 3 \mathrm{AR}$ protein abundance between treatments in adipose tissue. These results are supported by in vitro data from our laboratory, where we found no difference in $\beta 1 \mathrm{AR}$ or $\beta 2 \mathrm{AR}$ protein abundance of cells treated with $\mathrm{ZH}$ and $\mathrm{Zn}$ [3]. Furthermore, Harris [4] also reported no changes in $\beta 1 \mathrm{AR}$ and $\beta 2 \mathrm{AR}$ protein abundance of cells treated with RH and $\mathrm{Zn}$. Zinc methionine cattle had greater $(P<0.05$; Fig. 1) MHC-II protein abundance than CON. The MHC-II protein abundance includes type IIA and IIX. In addition, ZnMet cattle had an increased fiber cross-sectional area

Table 9 Effect of zinc methionine complex in combination with zilpaterol hydrochloride on relative protein concentration of $\beta 1 \mathrm{AR}$, $\beta 2 \mathrm{AR}$, and $\beta 3 \mathrm{AR}$ in semimembranosus and adipose tissue

\begin{tabular}{|c|c|c|c|c|}
\hline Receptor & $\mathrm{CON}^{\mathrm{a}}$ & $\mathrm{ZnMet}^{\mathrm{b}}$ & $\mathrm{SEM}^{\mathrm{c}}$ & $P$ value \\
\hline \multicolumn{5}{|c|}{ Semimembranosus } \\
\hline$\beta_{1}$ & 3435 & 3311 & 109.34 & 0.266 \\
\hline$\beta_{2}$ & 31,924 & 32,008 & 1018.98 & 0.934 \\
\hline$\beta_{3}$ & 9235 & 9612 & 461.14 & 0.418 \\
\hline \multicolumn{5}{|l|}{ Adipose } \\
\hline$\beta_{2}$ & 36,354 & 36,198 & 1429.45 & 0.913 \\
\hline$\beta_{3}$ & 35,159 & 34,662 & 1027.68 & 0.631 \\
\hline
\end{tabular}

${ }^{\text {a }} \mathrm{CON}$ : Control $90 \mathrm{ppm} \mathrm{Zn}$ added from $\mathrm{ZnSO}_{4}$ ( $n=20$ steers)

${ }^{\mathrm{b}}$ ZnMet: Control plus $720 \mathrm{mg} \mathrm{Zn}$ added from ZINPRO ${ }^{\circledR}$ zinc methionine ( $n=20$ steers)

${ }^{\mathrm{c}}$ Pooled standard error of the mean

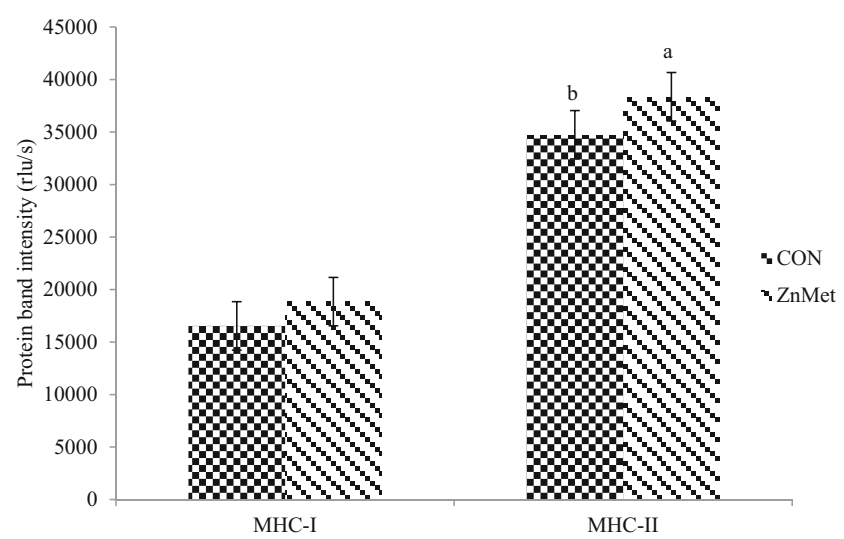

Fig. 1 Effect of zinc methionine complex in combination with zilpaterol hydrochloride on relative protein concentration of myosin heavy chain (MHC)-I and II semimembranosus tissue. CON: Control 90 ppm Zn added from $\mathrm{ZnSO}_{4}$ ( $n=20$ steers). ZnMet: Control plus $720 \mathrm{mg} \mathrm{Zn}$ added from ZINPRO ${ }^{\circledR}$ zinc methionine ( $n=20$ steers). There was no difference in protein concentration of MHC-I $(P=0.322$; pooled standard error of the mean $(\mathrm{SEM})=2305.27)$. There was a significant difference in the protein concentration of MHC-II $(P=0.001 ; \mathrm{SEM}=2021.73)$

of MHC-IIA and IIX fibers $(P<0.05$; Fig. 2). There was no difference $(P>0.05$; Fig. 1$)$ in MHC-I protein abundance and fiber cross-sectional area $(P>0.05$; Fig. 2$)$ between treatments.

Likewise, ZnMet cattle had a greater percentage of MHC-I fibers $(P<0.05$; Fig. 3$)$, and tended to have a greater percentage of MHC-IIA fibers $(P<0.10 ; 47.01$ vs $47.83 \%$ respectively). Control cattle had a greater percentage of MHC-IIX fibers $(P<0.05$; Fig. 3). Zilpaterol $\mathrm{HCl}$ has been shown to increase the percentage of MHC-IIX fibers in the longissimus lumborum, increase the percentage of MHC-IIX, and decrease

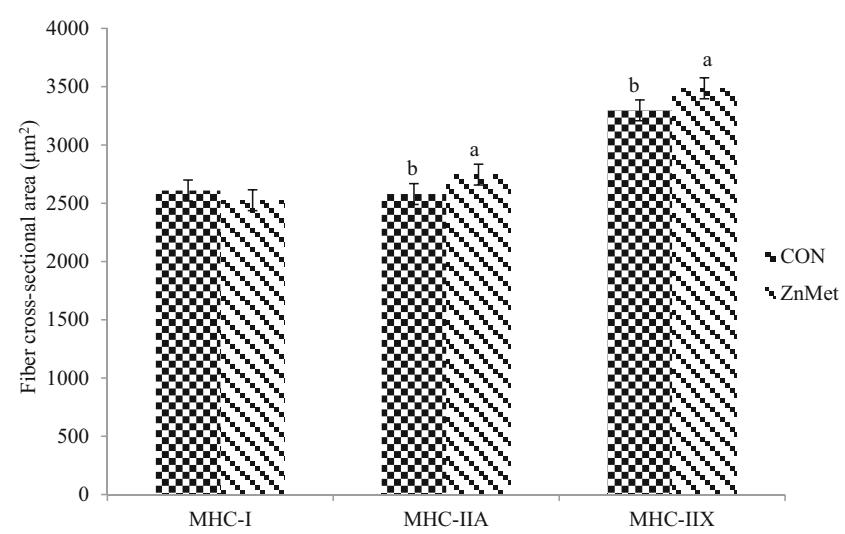

Fig. 2 Effect of zinc methionine complex in combination with zilpaterol hydrochloride on fiber cross-sectional area, $\left(\mu \mathrm{m}^{2}\right)$ in semimembranosus tissue. CON: Control $90 \mathrm{ppm} \mathrm{Zn}$ added from $\mathrm{ZnSO}_{4}$ ( $n=20$ steers). ZnMet: Control plus $720 \mathrm{mg} Z \mathrm{Zn}$ added from ZINPRO $^{\mathbb{Q}}$ zinc methionine $(n=20$ steers). There was no difference in fiber cross-sectional area of MHC-I $(P=0.353$; pooled standard error of the mean $(\mathrm{SEM})=89.756)$. There was a significant difference in the fiber cross-sectional area of MHC-IIA $(P=0.001$; SEM $=50.977)$ and MHC-IIX $(P=0.001$; SEM= 59.431) 


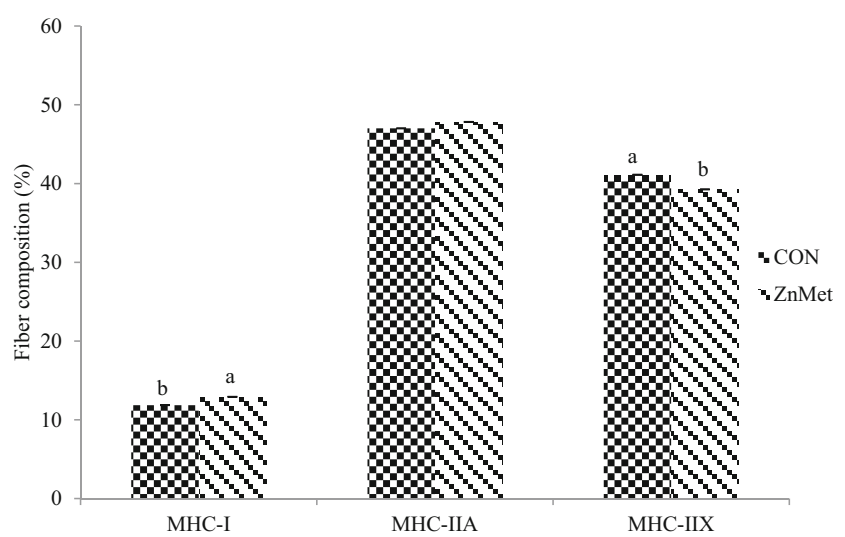

Fig. 3 Effect of zinc methionine complex in combination with zilpaterol hydrochloride on muscle fiber type composition in semimembranosus tissue. CON Control $90 \mathrm{ppm} \mathrm{Zn}$ added from $\mathrm{ZnSO}_{4}$ ( $n=20$ steers). ZnMet Control plus $720 \mathrm{mg} \mathrm{Zn}$ added from ZINPRO ${ }^{\mathbb{8}}$ zinc methionine $(n=20$ steers). There was a significant difference in composition of MHCI $(P=0.001$; pooled standard error of the mean $(\mathrm{SEM})=0.026)$ and MHCIIX $(P=0.001 ; \mathrm{SEM}=0.017)$. There was no difference in the composition of MHC-IIA $(P=0.069 ;$ SEM $=0.017)$

the percentage of MHC-I in the gluteus medius [8]. Paulk et al. [16] reported a linear decrease in the percent of MHC-IIA fibers as $\mathrm{Zn}$ concentration increased in pigs supplemented with RH and $\mathrm{Zn}$. There was a tendency for the percentage of MHC-IIX fibers to increase when supplemental $\mathrm{Zn}$ was fed in combination with RH [16].

Cattle not supplemented with ZnMet had the greater density of nuclei $(P<0.05$; Table 10$)$ and ZnMet cattle had a greater density of cells expressing Pax7 $(P<0.005$; Table 10). There was no difference in the density of cells expressing Myf5 and Pax7/Myf5 between treatments $(P>0.05)$. Knobel [8] reported that ZH supplementation decreased nuclei density in the longissimus lumborum, gluteus medius, and semimembranosus. Zilpaterol $\mathrm{HCl}$ did not affect satellite cell populations in the longissimus lumborum, gluteus medius, and semimembranosus [8].

When evaluating $\beta 1 \mathrm{AR}$, internalized $\beta 1 \mathrm{AR}$ and internalized $\beta 3 \mathrm{AR}$, no differences were detected $(P>0.05$; Table 11$)$.

Table 10 Effect of zinc methionine complex in combination with zilpaterol hydrochloride on nuclei and satellite cell density in semimembranosus tissue

\begin{tabular}{lrrrl}
\hline Item $\left(\mathrm{mm}^{2}\right)$ & $\mathrm{CON}^{\mathrm{a}}$ & $\mathrm{ZnMet}^{\mathrm{b}}$ & $\mathrm{SEM}^{\mathrm{c}}$ & $P$ value \\
\hline Total nuclei & 658.99 & 596.10 & 16.902 & 0.001 \\
Myofiber nuclei & 577.58 & 509.38 & 16.806 & $<0.001$ \\
Pax7 & 1.81 & 3.71 & 0.669 & 0.005 \\
Myf5 & 66.66 & 70.84 & 3.245 & 0.199 \\
Pax7+Myf5 & 12.92 & 12.16 & 1.583 & 0.628 \\
\hline
\end{tabular}

${ }^{\text {a }} \mathrm{CON}$ : Control $90 \mathrm{ppm} \mathrm{Zn}$ added from $\mathrm{ZnSO}_{4}$ ( $n=20$ steers)

${ }^{\mathrm{b}}$ ZnMet: Control plus $720 \mathrm{mg} \mathrm{Zn}$ added from ZINPRO ${ }^{\circledR}$ zinc methionine ( $n=20$ steers)

${ }^{\mathrm{c}}$ Pooled standard error of the mean
Table 11 Effect of zinc methionine complex in combination with zilpaterol hydrochloride on $\beta$-adrenergic receptor density in semimembranosus tissue

\begin{tabular}{lrrrr}
\hline Item $\left(\mathrm{mm}^{2}\right)$ & $\mathrm{CON}^{\mathrm{a}}$ & $\mathrm{ZnMet}^{\mathrm{b}}$ & $\mathrm{SEM}^{\mathrm{c}}$ & $P$ value \\
\hline$\beta_{1} \mathrm{AR}$ & 270.84 & 265.72 & 9.052 & 0.572 \\
$\beta_{1}$ AR-internalized & 0.13 & 0.26 & 0.189 & 0.476 \\
$\beta_{2} \mathrm{AR}$ & 350.77 & 308.81 & 10.537 & 0.001 \\
$\beta_{2} \mathrm{AR}$-internalized & 0.06 & 0.61 & 0.297 & 0.068 \\
$\beta_{3} \mathrm{AR}$ & 120.67 & 132.66 & 6.309 & 0.058 \\
$\beta_{3} \mathrm{AR}$-internalized & 0.06 & 0.26 & 0.148 & 0.175 \\
\hline
\end{tabular}

${ }^{\text {a }} \mathrm{CON}$ : Control $90 \mathrm{ppm} \mathrm{Zn}$ added from $\mathrm{ZnSO}_{4}$ ( $n=20$ steers)

${ }^{\mathrm{b}}$ ZnMet: Control plus $720 \mathrm{mg} \mathrm{Zn}$ added from $\mathrm{ZINPRO}^{\circledR}$ zinc methionine ( $n=20$ steers)

${ }^{\mathrm{c}}$ Pooled standard error of the mean

Control cattle had a greater density of $\beta 2 \mathrm{AR}(P<0.05)$, while ZnMet cattle tended to have a greater density of internalized $\beta 2$ AR $(P<0.10)$. Furthermore, ZnMet cattle tended to have a greater density of $\beta 3 \mathrm{AR}(P<0.10)$. These data indicate combining $\mathrm{ZnMet}$ and $\mathrm{ZH}$ did not affect growth performance; however, the combination of these supplements numerically increased the marbling score and the percentage of cattle that graded USDA Prime (1.30 and $4.35 \%$; CON vs ZnMet, respectively). Furthermore, fatty acid concentrations from the neutral lipid fraction, primarily triglycerides from adipocytes, were determined to be greater in ZnMet muscle tissue $(P<0.05$; Table 12). The slight increases observed in marbling score and cattle grading USDA Prime, along with increased concentrations of neutral lipid fatty acids in ZnMet cattle may be the result of decreased mRNA expression of Glut4 in subcutaneous adipose tissue. The effect of decreased mRNA expression of SCD in ZnMet cattle affected fatty acid composition and saturation. Through tabulation of fatty acids as percentages ( $\mathrm{g} / 100 \mathrm{~g}$ total fatty acids), it was determined that neutral lipid stearic acid (18:0) was greater in ZnMet $(P<0.05$; Tables 12 and 13). Meanwhile, oleic acid (18:1) was increased in CON neutral lipids $(P<0.05)$. These results are in agreement with SCD expression (Table 7) and show a direct impact on desaturation of 18:0 to $18: 1$.

While the mechanisms by which $\mathrm{Zn}$ enhances muscle hypertrophy when supplemented with $\beta$ AA have not been fully elucidated, there is speculation that $\beta 2 \mathrm{AR}$ potentially have multiple allosteric binding sites for $\mathrm{Zn}$ [28], allowing $\mathrm{ZH}$ to bind more efficiently to $\beta 2 \mathrm{AR}$ and elicit a greater effect on muscle hypertrophy. However, overstimulation of the $\beta$ AR by $\beta A A$ results in receptor desensitization $[31,33]$. Receptor desensitization prompts downregulation of adenylate cyclase catalytic activity, resulting in a reduction of cAMP synthesis and protein kinase A activation [32]. When the $\beta$ AR become desensitized, they are sequestered within an intracellular vesicle and lose the ability to propagate the signal transduction 
Table 12 Effect of zinc methionine complex in combination with zilpaterol hydrochloride on concentrations ( $\mathrm{mg} / \mathrm{g}$ muscle tissue) and percentages $(\mathrm{g} / 100 \mathrm{~g}$ total fatty acids) of individual neutral lipid fatty acids (FA) and FA categories (saturated fatty acids (SFA), monounsaturated (MUFA), and polyunsaturated fatty acids (PUFA)) of neutral and polar lipid fractions (LF) from semimembranosus tissue

\begin{tabular}{|c|c|c|c|c|c|c|c|c|}
\hline \multirow[t]{2}{*}{ FA } & \multicolumn{4}{|c|}{$\mathrm{mg} / \mathrm{g}$ muscle tissue } & \multicolumn{4}{|c|}{$\%, \mathrm{~g} / 100 \mathrm{~g}$ total FA } \\
\hline & $\mathrm{CON}^{\mathrm{a}}$ & $\mathrm{ZnMet}^{\mathrm{b}}$ & $\mathrm{SEM}^{\mathrm{c}}$ & $P$ value & $\mathrm{CON}^{\mathrm{a}}$ & $\mathrm{ZnMet}^{\mathrm{b}}$ & $\mathrm{SEM}^{\mathrm{c}}$ & $P$ value \\
\hline Total FA & $22.084 b$ & $34.047 \mathrm{a}$ & 4.907 & 0.046 & & & & \\
\hline$S F A$ & 10.225 & 16.537 & 2.285 & 0.054 & $45.988 b$ & $49.375 \mathrm{a}$ & 0.945 & 0.013 \\
\hline $14: 0$ & $0.832 b$ & $1.402 \mathrm{a}$ & 0.194 & 0.041 & 3.745 & 4.222 & 0.182 & 0.061 \\
\hline $15: 0$ & 0.125 & 0.198 & 0.026 & 0.051 & 0.589 & 0.600 & 0.026 & 0.766 \\
\hline $16: 0$ & 5.813 & 9.333 & 1.255 & 0.051 & $26.130 \mathrm{~b}$ & $28.051 \mathrm{a}$ & 0.694 & 0.049 \\
\hline $17: 0$ & 0.252 & 0.419 & 0.062 & 0.061 & 1.131 & 1.213 & 0.062 & 0.332 \\
\hline $18: 0$ & 3.141 & 5.111 & 0.759 & 0.069 & $14.085 \mathrm{~b}$ & $15.058 \mathrm{a}$ & 0.539 & 0.190 \\
\hline $23: 0$ & $0.013 \mathrm{a}$ & $0.008 \mathrm{~b}$ & 0.001 & 0.003 & 0.076 & 0.027 & 0.021 & 0.054 \\
\hline MUFA & 11.044 & 16.208 & 2.500 & 0.142 & $50.128 \mathrm{a}$ & $46.635 b$ & 0.941 & 0.010 \\
\hline $14: 1$ & 0.293 & 0.464 & 0.065 & 0.064 & 1.304 & 1.450 & 0.107 & 0.320 \\
\hline $16: 1$ & 0.828 & 1.253 & 0.163 & 0.068 & 3.721 & 3.943 & 0.242 & 0.499 \\
\hline $17: 1$ & 0.233 & 0.364 & 0.052 & 0.076 & 1.049 & 1.107 & 0.063 & 0.501 \\
\hline 18:1 trans & $1.089 \mathrm{~b}$ & $1.929 \mathrm{a}$ & 0.269 & 0.031 & 5.139 & 5.545 & 0.366 & 0.414 \\
\hline $18: 1$ cis-9 & 8.469 & 11.976 & 1.972 & 0.204 & $38.302 \mathrm{a}$ & $33.911 \mathrm{~b}$ & 1.154 & 0.009 \\
\hline $20: 1$ & $0.131 b$ & $0.220 \mathrm{a}$ & 0.027 & 0.026 & 0.611 & 0.678 & 0.030 & 0.115 \\
\hline PUFA & $0.815 b$ & $1.302 \mathrm{a}$ & 0.161 & 0.037 & 3.881 & 3.992 & 0.188 & 0.665 \\
\hline $18: 2 n-6$ & $0.622 b$ & $0.998 \mathrm{a}$ & 0.123 & 0.033 & 2.987 & 3.058 & 0.155 & 0.733 \\
\hline $18: 3 n-3$ & $0.038 \mathrm{~b}$ & $0.066 \mathrm{a}$ & 0.008 & 0.024 & 0.181 & 0.200 & 0.009 & 0.163 \\
\hline $20: 3 n-6$ & 0.018 & 0.028 & 0.004 & 0.095 & 0.085 & 0.084 & 0.008 & 0.966 \\
\hline $20: 4 n-6$ & 0.041 & 0.044 & 0.004 & 0.605 & 0.227 & 0.164 & 0.035 & 0.188 \\
\hline
\end{tabular}

Means in the same row having different letters are significant at $P \leq 0.05$ due to $\mathrm{ZnMet} / \mathrm{CON} \times \mathrm{LF}$ interaction

${ }^{\text {a }} \mathrm{CON}$ : Control $90 \mathrm{ppm} \mathrm{Zn}$ added from $\mathrm{ZnSO}_{4}$ ( $n=20$ steers)

${ }^{\mathrm{b}} \mathrm{ZnMet}$ : Control plus $720 \mathrm{mg} \mathrm{Zn}$ added from $\mathrm{ZINPRO}^{\mathbb{B}}$ zinc methionine ( $n=20$ steers)

${ }^{\mathrm{c}}$ Pooled standard error of the mean pathway $[31,33]$. The decreased density of $\beta 2 A R$ on the cell surface and increased density of internalized $\beta 2 A R$ in the ZnMet cattle suggests that the $\beta 2 \mathrm{AR}$ were desensitized and sequestered within an intracellular vesicle. The desensitization of the $\beta 2 \mathrm{AR}$ may have occurred due to the allosteric binding of $\mathrm{Zn}$ to the $\beta 2 \mathrm{AR}$, increasing the affinity for $\mathrm{ZH}$ to bind to the receptor. While the affinity of the $\beta 2 A R$ may have been enhanced, the hypothesized positive implications on hypertrophy and performance were not observed in this study. Thus, future research should focus on the relationship in which zinc alters affinity and its interaction with muscle hypertrophy.

When evaluating the protein abundance of MHC and crosssectional area of the fibers, the ZnMet cattle had a greater abundance of MHC-II protein and had greater crosssectional areas for MHC-IIA and IIX fibers. The ZnMet treatment also increased the percentage of MHC-I and IIA fibers while decreasing the percentage of MHC-IIX fibers, indicating that $\mathrm{Zn}$ supplementation may alter fiber type by increasing the percentage of the more oxidative fibers. The mRNA expression supports the previous statement, as the ZnMet treatment had increased expression of MHC-I and decreased expression of MHC-IIX. The increase in MHC-II protein concentration and MHC-IIA and IIX fiber cross-sectional areas observed coupled by a decreased percentage of MHC-IIX fibers in the ZnMet treatment is an interesting phenomenon. Typically, as fiber cross-sectional area increases, the fiber types will transition to the more glycolytic fiber types [17, 18]. The ZnMet treatment had a lower density of total and myofiber nuclei, which was an expected dilution effect with increases in fiber cross-sectional area. Essentially, the ZnMet treatment had a greater cross-sectional muscle fiber area being regulated by fewer nuclei. However, it is important to note that the total nuclei density reported in this study includes nuclei associated with the satellite cells. While the ZnMet cattle had the least total nuclei density, they had the greatest density of Pax7-expressing satellite cells. The expression of Pax7 is required for adult muscle satellite cells to form and proliferate $[20,22]$, and Pax7 satellite cells still maintain the ability to proliferate [30]. After proliferation, satellite cells either downregulate Pax7 and enter into differentiation or maintain Pax7 and stop expressing myogenic determination factor 1 and revert to a quiescent state [30]. The increased density of Pax7expressing satellite cells in the ZnMet treatment suggests that those animals have the ability to increase the total nuclei and myofiber nuclei through the proliferation and differentiation of the Pax 7 satellite cells. The ability to increase the myofiber 
Table 13 Effect of zinc methionine complex in combination with zilpaterol hydrochloride on concentrations (mg/g muscle tissue) and percentages $(\mathrm{g} / 100 \mathrm{~g}$ total fatty acids) of individual polar lipid fatty acids (FA) and FA categories (saturated fatty acids (SFA), monounsaturated (MUFA), and polyunsaturated fatty acids (PUFA)) of neutral and polar lipid fractions (LF) from semimembranosus tissue

\begin{tabular}{|c|c|c|c|c|c|c|c|c|}
\hline \multirow[t]{2}{*}{ FA } & \multicolumn{4}{|c|}{$\mathrm{mg} / \mathrm{g}$ muscle tissue } & \multicolumn{4}{|c|}{$\%, \mathrm{~g} / 100 \mathrm{~g}$ total FA } \\
\hline & $\mathrm{CON}^{\mathrm{a}}$ & $\mathrm{ZnMet}^{\mathrm{b}}$ & SEM $^{\mathrm{c}}$ & $P$ value & $\mathrm{CON}^{\mathrm{a}}$ & $\mathrm{ZnMet}^{\mathrm{b}}$ & SEM $^{\mathrm{c}}$ & $P$ value \\
\hline Total FA & 1.913 & 2.212 & 0.197 & 0.292 & & & & \\
\hline$S F A$ & 0.752 & 0.909 & 0.084 & 0.197 & 41.523 & 40.829 & 1.207 & 0.678 \\
\hline $14: 0$ & 0.041 & 0.051 & 0.007 & 0.318 & 2.271 & 2.278 & 0.206 & 0.980 \\
\hline $15: 0$ & 0.016 & 0.017 & 0.001 & 0.280 & 0.791 & 0.821 & 0.043 & 0.619 \\
\hline $16: 0$ & 0.413 & 0.482 & 0.053 & 0.369 & 21.421 & 21.393 & 0.577 & 0.972 \\
\hline $17: 0$ & 0.011 & 0.013 & 0.002 & 0.678 & 0.630 & 0.568 & 0.065 & 0.498 \\
\hline $18: 0$ & 0.280 & 0.336 & 0.028 & 0.172 & 15.873 & 15.163 & 0.826 & 0.536 \\
\hline 23:0 & 0.014 & 0.011 & 0.001 & 0.255 & 0.758 & 0.691 & 0.137 & 0.727 \\
\hline$M U F A$ & 0.576 & 0.544 & 0.057 & 0.701 & 32.358 & 32.791 & 2.079 & 0.880 \\
\hline $14: 1$ & 0.020 & 0.023 & 0.002 & 0.361 & 1.119 & 1.186 & 0.074 & 0.513 \\
\hline $16: 1$ & 0.039 & 0.047 & 0.007 & 0.431 & 2.190 & 2.074 & 0.172 & 0.625 \\
\hline $17: 1$ & 0.015 & 0.018 & 0.002 & 0.427 & 0.865 & 0.790 & 0.049 & 0.272 \\
\hline 18:1 trans & 0.055 & 0.071 & 0.009 & 0.194 & 3.038 & 3.282 & 0.248 & 0.480 \\
\hline $18: 1$ cis-9 & 0.429 & 0.429 & 0.047 & 0.997 & 24.198 & 24.644 & 1.662 & 0.846 \\
\hline $20: 1$ & 0.019 & 0.020 & 0.001 & 0.625 & 1.058 & 1.064 & 0.163 & 0.979 \\
\hline PUFA & 0.525 & 0.567 & 0.040 & 0.467 & 26.119 & 26.378 & 2.333 & 0.936 \\
\hline $18: 2$ n-6 & 0.287 & 0.322 & 0.023 & 0.304 & 14.366 & 14.961 & 1.267 & 0.734 \\
\hline $18: 3 n-3$ & $0.008 \mathrm{~b}$ & $0.009 \mathrm{a}$ & $<0.001$ & 0.014 & 0.373 & 0.395 & 0.033 & 0.630 \\
\hline $20: 3 n-6$ & 0.040 & 0.043 & 0.003 & 0.581 & 2.008 & 1.994 & 0.204 & 0.958 \\
\hline $20: 4 n-6$ & 0.191 & 0.195 & 0.014 & 0.836 & 9.426 & 9.146 & 0.895 & 0.821 \\
\hline
\end{tabular}

Means in the same row having different letters are significant at $P \leq 0.05$ due to $\mathrm{ZnMet} / \mathrm{CON} \times \mathrm{LF}$ interaction

${ }^{\text {a }} \mathrm{CON}$ : Control $90 \mathrm{ppm} \mathrm{Zn}$ added from $\mathrm{ZnSO}_{4}(n=20$ steers)

${ }^{\mathrm{b}} \mathrm{ZnMet}$ : Control plus $720 \mathrm{mg} \mathrm{Zn}$ added from ZINPRO ${ }^{\circledR}$ zinc methionine ( $n=20$ steers)

${ }^{\mathrm{c}}$ Pooled standard error of the mean nuclei implies possible enhancement in muscle hypertrophy in the $\mathrm{ZnMet}$ treatment.

While there is little data on the interactions of $\mathrm{Zn}$ source, $\beta A A$, and $\beta A R$ on growth and the biological process involved in these changes, these compounds have been individually studied extensively. Previous data reports that ZnMet supplementation often times increases fat thickness, as well as MS and QG which may possibly have an economic impact $[3,6,21]$. However, ZnMet supplementation has been shown to have varying effects on feedlot performance. Studies have shown that ZnMet improved ADG and feed efficiency [24, 25], while others have reported no difference in $A D G$ or feed efficiency [3, 6, 21]. Conversely, ZH supplementation has consistently been shown to improve feedlot and carcass performance [19, 26, 29, 34]. Studies have reported ZH improved feed to gain, HCW, dressing percentage, and LMA while decreasing backfat thickness $[19,26,29,34]$. While the combination of ZnMet and ZH had positive effects on the molecular level (MHC isoforms and cross-sectional area), there were minimal effects on overall feedlot and carcass performance. The lack of feedlot and carcass performance in this study may implicate that the animal was already at its maximum potential due to $\mathrm{ZH}$ supplementation, and may not be capable of additional growth performance. The mechanisms by which ZnMet and ZH interact to elicit effects on performance, lipid metabolism, and myogenic activity is still unknown, and future research should be conducted to further elucidate the molecular mechanisms that impact muscle and adipose metabolism in biological processes involving ZnMet and other growth promotant technologies.

Open Access This article is distributed under the terms of the Creative Commons Attribution 4.0 International License (http:// creativecommons.org/licenses/by/4.0/), which permits unrestricted use, distribution, and reproduction in any medium, provided you give appropriate credit to the original author(s) and the source, provide a link to the Creative Commons license, and indicate if changes were made.

\section{References}

1. Federation of Animal Science Societies (2010) Guide for the care and use of agriculture animals in research and teaching. $3^{\text {rd }}$ ed. http://www.fass.org

2. Folch J, Lees M, Stanley HS (1957) A simple method for the isolation and purification of total lipids from animal tissues. J Biol Chem 226:497-509 
3. Greene LW, Lunt DK, Byers FM, Chirase NK, Richmond CE, Knutson RE, Schelling GT (1988) Performance and carcass quality of steers supplemented with zinc oxide or zinc methionine. J Anim Sci 66:1818-1823

4. Harris $\mathrm{T}$ (2013) The effect of zinc on the $\beta$-adrenergic receptor in bovine satellite cells and the use of $\beta$-agonists and steroid implants on muscle protein and mRNA levels in feedlot cattle. Master Thesis. Texas Tech University, Lubbock

5. Hergenreder JE, Baggerman JO, Hosford AD, Branine ME, Johnson BJ (2014) Interactive effects of zinc and zilpaterol hydrochloride on the bovine $\beta$-adrenergic receptors. J Anim Sci 92(Suppl 2):43, Abstr

6. Huerta M, Kincaid RL, Cronrath JD, Busboom J, Johnson AB, Swenson CK (2002) Interaction of dietary zinc and growth implants on weight gain, carcass traits and zinc in tissues of growing beef steers and heifer. Anim Feed Sci Tech 95:15-32

7. Juaneda P, Rocquelin G (1982) Rapid and convenient separation of phospholipids and non-phosphorous lipids from rat heart using silica cartridge. Lipids 20(1):40-41

8. Knobel SM (2014) Investigation of mechanisms responsible for change in shear force value of various muscles from implanted beef cattle fed zilpaterol hydrochloride and supplemental vitamin $\mathrm{D}_{3}$. $\mathrm{Ph}$. D. Dissertation. Texas Tech University, Lubbock

9. Legako JF, Dinh TTN, Miller MF, Brooks JC (2015) Effects of USDA beef quality grade and cooking on fatty acid composition of neutral and polar lipid fractions. Meat Sci 100:246-255

10. Li Y, Watkins BA (2001) Analysis of fatty acids in food lipids. In: Wrolstad RE (ed) Current protocols in food analytical chemistry. Wiley, New York, pp D1.2.1-D1.2.15

11. Maxwell RJ, Marmer FH (1983) Systemic protocol for accumulation of fatty acid data from multiple tissue samples: tissue handling, lipid extraction and class separation, and capillary gas chromatographic analysis. Lipids 18:453-459

12. Mersmann HJ (1998) Overview of the effects of beta-adrenergic receptor agonists on animal growth including mechanism of action. J Anim Sci 76:160

13. Miller EK, Chung KY, Hutcheson JP, Yates DA, Smith SB, Johnson BJ (2012) Zilpaterol hydrochloride alters abundance of $\beta$ adrenergic receptors in bovine muscle cells but has little effect on de novo fatty acid biosynthesis in bovine subcutaneous adipose tissue explants. J Anim Sci 90:1317-1327

14. NRC (1996) Nutrient requirements of beef cattle, 7th edn. Natl. Acad. Press, Washington, DC

15. Oh YS, Choi CB (2004) Effects of zinc on lipogenesis of bovine intramuscular adipocytes. Asian-Aust J Anim Sci 10:1378-1382

16. Paulk CB, Tokach MD, Nelssen JL, Burnett DD, Vaughn MA, Phelps KJ, Dritz SS, DeRouchey JM, Goodband RD, Woodworth JC, Houser TA, Haydon KD, Gonzalez JM (2014) Effect of dietary zinc and ractopamine hydrochloride on pork chop muscle fiber type distribution, tenderness, and color characteristics. J Anim Sci 92: 2325

17. Pette D, Staron RS (2000) Myosin isoforms, muscle fiber types, and transitions. Microscopy Res Tech 50:500

18. Peirobon-Bormioli S, Sartore S, Libera LD, Vitadello M, Schiaffino S (1981) "Fast" isomyosins and fiber types in mammalian skeletal muscle. J Histochem Cytochem 29:1179
19. Rathmann RJ, Bernhard BC, Swingle RS, Lawrence TE, Nichols WT, Yates DA, Hutcheson JP, Streeter MN, Brooks JC, Miller MF, Johnson BJ (2012) Effects of zilpaterol hydrochloride and days on the finishing diet on feedlot performance, carcass characteristics, and tenderness in beef heifers. J Anim Sci 90:3301-3311

20. Rhoads RP, Rathbone CR, Flann KL (2009) Satellite Cell Biology. In: Du M, McCormick RJ (eds) Applied muscle biology and meat science. CRC Press, Boca Raton, pp 47-68

21. Rust SR (1985) Effects of zinc methionine and grain processing on performance of growing-fattening steers. J Anim Sci 61(Suppl 1): 482, Abstr

22. Seale P, Sabourin LA, Girgis-Gabardo A, Mansouri A, Gruss P, Rudnicki MA (2000) Pax7 is required for the specification of myogenic satellite cells. Cell 102:777

23. Spears JW (1996) Organic trace minerals in ruminant nutrition. Anim Feed Sci Tech 58:151-163

24. Spears JW (1989) Zinc methionine for ruminants: relative bioavailability of zinc in lambs and effects of growth and performance on growing heifers. J Anim Sci 67:835-843

25. Spears JW, Samsell LJ (1986) Relative availability of zinc in zinc methionine and zinc oxide for ruminants. J Anim Sci 63(Suppl 1): 402, Abstr

26. Strydom PE, Frylinck L, Montgomery JL, Smith MF (2009) The comparison of three b-agonists for growth performance, carcass characteristics and meat quality of feedlot cattle. J Meat Sci 81: 557-564

27. Swaminath G, Steenhuis J, Kobilka B, Lee TW (2002) Allosteric modulation of $\beta_{2}$-adrenergic receptor by $\mathrm{Zn}^{2+}$. Mol Pharmacol 61: $65-72$

28. Swaminath G, Lee TW, Kobilka B (2003) Identification of an allosteric binding site for $\mathrm{Zn}^{2+}$ on the $\beta_{2}$ adrenergic receptor. J Bio Chem 278:353-356

29. Vasconcelos JT, Rathmann RJ, Reuter RR, Leibovich J, McMeniman JP, Hales KE, Covey TL, Miller MF, Nichols WT, Galyean ML (2008) Effects of duration of zilpaterol hydrochloride feeding and days on the finishing diet on feedlot cattle performance and carcass traits. J Anim Sci 86:2005-2015

30. Zammit PS, Relaix F, Nagata Y, Ruiz AP, Collins CA, Partridge TA, Beauchamp JR (2006) Pax7 and myogenic progression in skeletal muscle satellite cells. J Cell Sci 119:1824

31. Lohse MJ, Benovic JL, Caron MG, Lefkowitz RJ (1990) Multiple pathways of rapid $\beta_{2}$-adrenergic receptor desensitization. J Biol Chem 265:3202

32. Pippig S, Andexinger S, Daniel K, Puzicha M, Caron MG, Lefkowitz RJ, Lohse MJ (1993) Overexpression of beta-arrestin and beta-adrenergic receptor kinase augment desensitization of beta 2-adrenergic receptors. J Biol Chem 268:3201-3208

33. Waldo GL, Northup JK, Perkins JP, Harden TK (1983) Characterization of an altered membrane form of the $\beta$ adrenergic receptor produced during agonist-induced desensitization. J Biol Chem 258:13900-13908

34. Scramlin SM, Platter WJ, Gomez RA, Choat WT, McKeith FK, Killefer J (2010) Comparative effects of ractopamine hydrochloride and zilpaterol hydrochloride on groath performance, carcass traits, and longissimus tenderness of finishing steers. J Anim Sci 88:1823 